\title{
Woda jako element idei i kompozycji w architekturze Tadao Ando
}

\section{Water as an element of the idea and composition in Tadao Ando's architecture}

\begin{abstract}
Streszczenie
Tadao Ando to japoński twórca kojarzony zazwyczaj z architekturą betonową. W jego ascetycznych, utrzymanych w nurcie minimalizmu realizacjach dostrzec można udane przykłady włączenia elementów natury w geometrię tworzonej przez niego architektury. Woda stanowi jeden z kluczowych elementów natury, który Ando wykorzystuje zarówno do kształtowania głównej idei architektonicznej budynku, jak i do komponowania formy obiektu czy jego bezpośredniego otoczenia. Analizując dokonania realizacyjne Ando należy uznać go za jednego z najbardziej konsekwentnych architektów współczesności, który w tak różnorodny sposób wprowadza element wody do swoich licznych projektów. Na przykładzie dokonań Tadao Ando starano się wskazać możliwości estetycznego wykorzystania elementu wody we współczesnej architekturze, który to znajduje zastosowanie zarówno w kształtowaniu zamysłu głównej idei architektonicznej budynku, jak i jako środek kompozycji w tworzeniu wyrafinowanej i subtelnej formy obiektu oraz jego najbliższego otoczenia.
\end{abstract}

\begin{abstract}
Tadao Ando is a Japanese artist usually associated with concrete architecture. His ascetic minimalist works include examples that successfully incorporate the elements of nature into the geometry of the architecture he creates. Water constitutes one of the key elements of nature that Ando uses both to shape the main architectural idea of the building and to compose the form of the structure or its immediate surroundings. The analysis of the artist's architectural achievements allows one to consider Ando one of the most consistent contemporary architects who introduces water element to his numerous projects in such a variety of ways. Presenting Tadao Ando's achievements, the author attempts to indicate the possibilities of the aesthetic use of water in contemporary architecture, which finds application both in shaping the main architectural idea of the building and, as a means of composition, in creating a refined and subtle form of the structure and its immediate surroundings.
\end{abstract}

Słowa kluczowe: Tadao Ando, woda w architekturze, woda jako element idei architektonicznej, woda w kompozycji i budowie formy architektonicznej, woda jako element zagospodarowaniu terenu

Keywords: Tadao Ando, water in architecture, water as an element of an architectural idea, water in the composition and construction of an architectural form, water as an element of land development

\section{Wprowadzenie}

Odwołując się do starożytnych mędrców przywołać można postać Talesa z Miletu, który za początek wszechrzeczy uznawał wodę. Według niego woda była ostateczną substancją, z której stworzone są wszystkie rzeczy ${ }^{1}$. Nie bez przyczyny także Witruwiusz w swym antycznym traktacie o architekturze pisał, że: „Woda jest najbardziej potrzebna dla codziennego życia, jak i jego przyjemności"2. Istotę tego stwierdzenia obrazuje choćby utrwalone w modelu rzymskiego domu atrialnego impluvium ${ }^{3}$ - centralnie zaplanowane w strukturze budynku miejsce (basen) na wodę, wokół którego toczyło się codzienne życie mieszkańców i dookoła którego rozmieszczano pozostałe przestrzenie mieszkalne. Nie dziwi zatem fakt, że woda bywa wykorzystywana jako główny element zamysłu idei kompozycyjnej wielu budynków, towarzysząc od zarania dziejów architektonicznej działalności człowieka. Ma to

\section{Introduction}

Referring to the ancient sages, one can recall the figure of Thales of Miletus who recognized water as the origin of all things. According to him, water was the ultimate substance which all other things were created from ${ }^{1}$. It is not without reason that Vitruvius wrote in his ancient treatise on architecture that water "is of infinite importance, for the purposes of life, for pleasure, and for our daily use $^{\prime \prime 2}$. The essence of this statement is illustrated by the impluvium ${ }^{3}$ established in the model of the Roman atrium house - a place (basin) for water centrally planned in the structure of the building, around which everyday life of the inhabitants took place and the remaining living spaces were arranged. It is not surprising, therefore, that water is used as the main element in the design of the compositional idea of a number of buildings, accompanying the architectural activity of man 
miejsce zarówno w odniesieniu do prywatnych domów jak i w archickurze budowli publicznych czy też dotyczy całych założeń urbanistycznych. Jest tak i dziś, jednak sposób w jaki wykorzystuje sie kompozycyjnie element wody we wspótczesnej architekturze posiada niejednokrotnie odmienny ideowo charakter od tego, znanego z poprzednich - tzw. przednowoczesnych epok. Jest on czesto ukierunkowany na wyrafinowane efekty estetyczne, starajace sie przypisać zamierzonym rzeczom aure wyjatkowości i wizuar ności, czy też próbuje nadać im znaczenie symboliczne poprzez stosownie poprowadzona przez twórce narracie czy gre przez czy tez probbje nadac in znece

Wielu wspótczesnych twórców siega po element wody, niejako ujarzmiając go architektonicznymi ramami i sztucznie wprowadzajacc ten element natury do kompozycii budowli lub jej bezpośredniego otoczenia. Za przykład może tu posłużyć znaczący dorobek twórczy Tadao Ando, obfitujący w liczne realizacje wykorzystujące element wody, czyniąc z niego jeden z kluczowych czynników natury, który wspoltworzy pewną ideologię projektową, mającą ściste powiązania z estetyką japonskiego minimalizmu oraz modernistyczną geometria form. Jak to ujął sam Ando: „Dążę do włączenia natury w architekturę tworzoną na podstawie przejrzystej logiki. Elementy natury - woda, wiatr, swiatio i niebo - sprawiaja, ze architektura wyprowadzona z myslenia ideologicznego schodzi do poziomu rzeczywistości i otwiera się na ludzkie życie" ${ }^{\prime \prime}$. Miho Iwata, przywołujacc przykłady z dorobku realizacyjnego Japończyka twierdzi, że: „Tadao Ando z prostej formy tworzy architekturę pełną dramaturgii i emocji. Wprowadzenie natury do życia i do architektury stanowi ważny temat w twórczości artysty. Jest to sztuka poszukująca właściwej relacji między przyroda a człowiekiem. Odizolowanie od świata zewnetrznego, wprowadzenie natury na nowo do wnetrza budynku, stworzenie przestrzeni kontemplacyjnych - to główne załozenia twórczości Tadao Ando"s.

2. Woda jako jeden z podstawowych elementów natury wykorzystywanych przez Tadao Ando w ksztaltowaniu idei i symborziki sacrum w architekturze budowli światynnych Wydaje się, że Ando najdobitniej wykorzystał ideologiczne znaczenie wody w projektach dotyczacych architektury sakralnej. Uczynił z niej kluczowy element kompozycji architekkranicznej wielu budynków, któremu przypisał znaczenie symtonicznej wielu budynkow, ktoremu przypisał znaczenie sym-
boliczne - znajdujące swe odzwierciedlenie także $w$ nazwie. boliczne - znajdujące swe odzwierciedlenie także w nazwie.
Wystarczy wspomnieć projekty kilku świątyń - Church on Wystarczy wspomnieć projekty kilku świątyn - Church on
the Water (Yufutsu, Hokkaido, Japonia, 1985-1988) czy Water the Water (Yufutsu, Hoksaido, Japonia, Jompuku-ji (Tsuna-gun, Hyogo, Japonia, 1989-1991). Element wody zyskat także kluczowe znaczenie w Komyo-ji Temple (Saijo, Ehime, Japonia, 1998-2000) czy w niewielkim założeniu Meditation Space (Paryż, Francja, 1994-1995). Aby przekonac się jak duze znaczenie przywiązuje Ando do elementów natury w swoich projektach wystarczy przywołac jego stwierdzenie obrazujące cel ich wykorzystania: „Kiedy woda, wiatr, światło, deszcz i inne elementy natury zostana w architekturze wyrażone, stanie się ona miejscem w którym ludzie i natura będą się spotykać w nieustannym poczuciu since the dawn of time. This applies to both private houses and public buildings or mas even extakes place today however, the way in This also element of water is used compositionaly in the temporary architecture is often ideologically different from the one known from the previous - the so-called pre-modern - eras. It is often oriented on sophisticated aesthetic effects, striving to attribute the aura of uniqueness and visual attractiveness to a symbolic meaning through a narrative or spatial game led expediently by the creator. This frequently allows buildings to gain the status of a work of art or an icon of modern architecture.

A number of contemporary artists reach for the element of water, taming it somewhat with architec-
tural frames and artificially introducing this natural element into the composition of the building or it immediate surroundings. A good example here is Tadao Ando's considerable creative achievements abounding in numerous works that make use of tors of nature, which co-creates a certain design ideology that has close links with the aesthetics of Japanese minimalism and modernist geometry of forms. As Ando once put it himself: "I seek to instil the presence of nature within an architecture logic. The elements of nature - water, wind light and sky - bring architecture derived from ideological thought down to the ground level of reality and awaken manmade life within it $\mathrm{it}^{\prime 4}$. Referring to the examples from the creative achievements of the Japanese artist, Miho Iwata claims that: "Tadao Ando creates architecture full of dramaturgy and to life and architecture is an important theme in the artist's creative work. This is an art that looks for the right relationship between nature and man. Isolation from the outside world, introduction of nature back into the interior of the building, creatio dations of Tadao Ando's creative work"

2. Water as one of the basic elements of nature used by Tadao Ando in shaping the idea and symbuildings

It seems that Ando has used the ideological sigrelated to sacred architecture. He has made it a key element of the architectural composition of a num ber of buildings and assigned a symbolic meaning suffice to mention the designs of several temples - such as Church on the Water (Yufutsu, Hokkaido Japan, 1985-1988) or Water Temple Hompuku(Tsuna-gun, Hyogo, Japan, 1989-1991). The element of water has also gained key significance in or in the small complex of the Meditation Space (Paris, France, 1994-1995). To see what importance Ando attaches to the elements of nature in his projects, it is enough to recall his statement tha illustrates the purpose of their use: "When water, wind, light, rain, and other elements of nature are
abstracted within architecture, the architecture becomes a place where people and nature confront each other under a sustained sense of tension. napięcia. Wierzę, że uczucie to pobudzi duchową wrazliwośc architektury powodujacej u odbiorcy (widza) owo „nieustanne poczucie napięcia" stało sie znakiem rozpoznawczym twórczości Ando. Powstaje ono dzięki przemyślanemu i rygorystycznemu wprowadzaniu elementów natury do projektów w sposób niebędacy ich uzupełnieniem czy dopełnieniem przyjetej koncepcii, lecz nieodzowną ich cześcią - stanowiacca logiczna i celowa konsekwencje przyjetego zamysłu idei architektonicznej budowli. Woda, obok światta czy wiatru, jest chitektonicze budro Woda, obok swatla czy wiatru, jes t poda budynku jak i w komponowaniu jego formy.

przypadku projektu Church on the Water - jak opisuje to Masao Furuyama: „Z naturalnego strumyka utworzono sztuczne jezioro, które stało się tlem dla geometrycznej bryły kościoła. Ten pejzaż, połaczenie naturalnej scenerii, ogrodu i budynku w całość założenia sprawia, że prezentuje ono najwyższy poziom japońskiej architektury krajobrazu" ${ }^{\prime \prime}$. W tej niewielkiej świątyni tradycyjną ścianę zamykającą prezbiterium Ando zamienit na kadr perspektywiczny ukazujący starannie przekształcony i wyrezyserowany krajobraz przepełniony symboliką poziomej tafli płytkiej wody sztucznie ukształtowanego zbiornika $z$ ktorej wyrasta samotna i wymowna forma stalowego, prezentującego się na tle naturalnego drzewostanu krzyża (ii.1). Będąc we wnętrzu, całość sprawia wrażenie tytułowego kościoła wzniesionego na wodzie - zamysłu architektonicznego, ktory dzięki temu elementowi natury zyska nie tylko wizualną atrakcyjność, ale i religijny przekaz. W 199 roku Ando stwierdzit: "Chcę umieścić siłę natury w dzisiej-

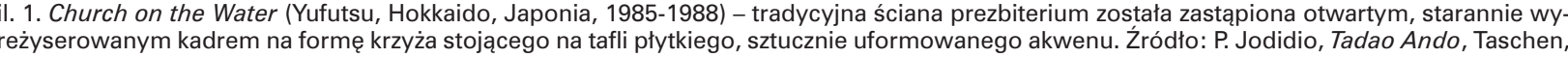
Köln 2001, s. 82 the Water (Yufutsu, Hokkaido, Japan, 1985-1988) - the traditional wall of the presbytery has been replaced by an open frame,
III. 1. Church on the
carefully directed on the form of a cross standing on the surface of a shallow artificicillly constructed pond. Source: P. Jodidio, Tadao Ando, Taschen,
Köln 2001 . p. 82

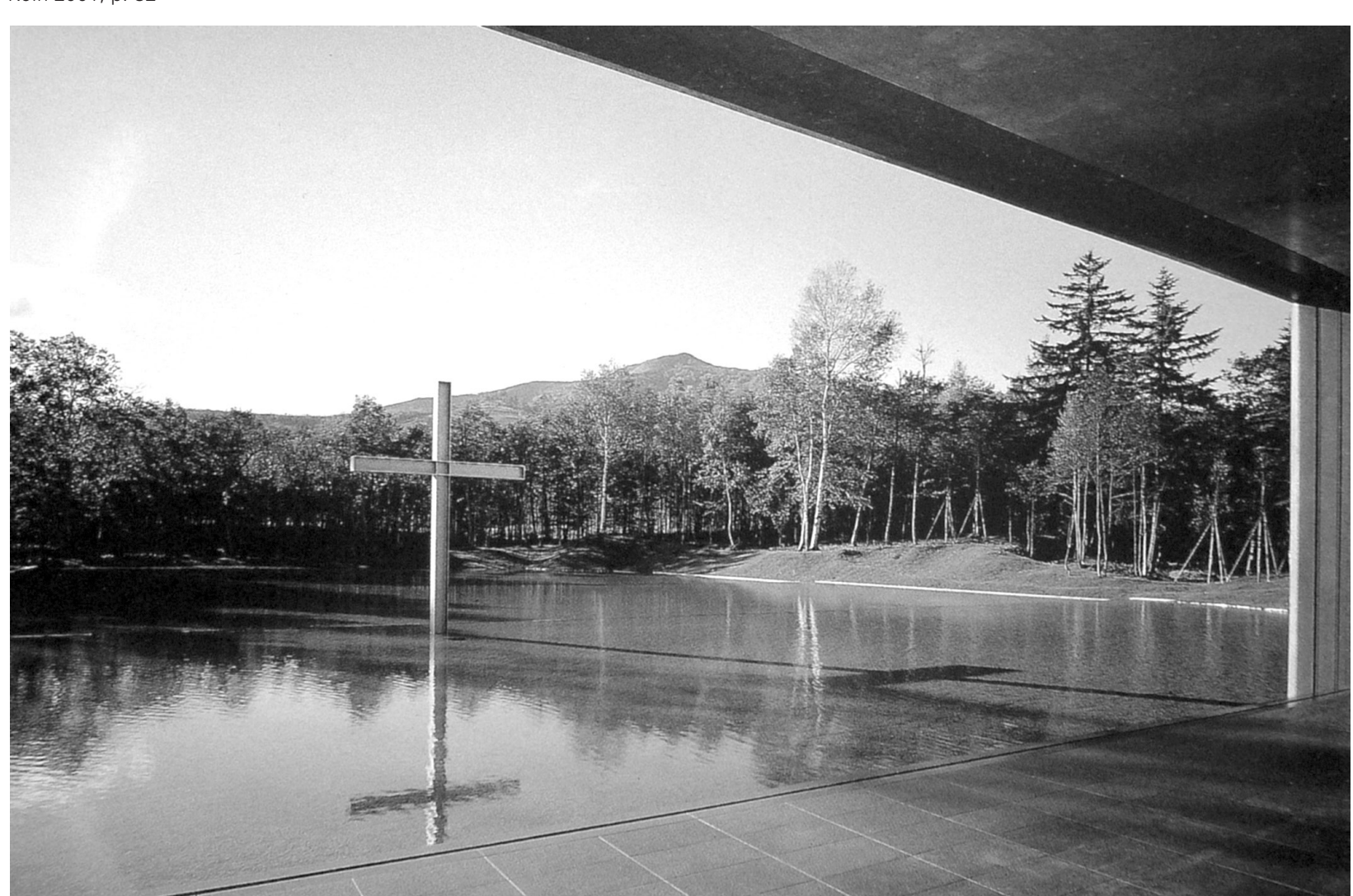

Ibelieve it is this feeling of tension that will awaken the spiritual sensibilities latent in contemporary that evokes the "sustained sense of tension" in the recipient (viewer) has become the hallmark of Anthe work. It arises owing to the thoughtnature to the projects in a way that is neither their complement nor completion of the adopted contuting a logical and deliberate consequence of the along with light or wind, is the basic element of
nature used by the Japanese architect both in shaping the architectural idea of the building and in composing its form.

described by Masao Furuyama: "The artificial - as which became the background for the geometric body of the church, was created from a natural scenery, garden and the building into the whole of Japanese landscape architecture ${ }^{\prime \prime}$. In this small temple, Ando turned a traditional wall closing the presbytery into a perspective frame revealing filled with the symbolism of a horizontal surface of shallow water in the artificially formed pond, of a steel cross, presenting itself against the backthe interior, the whole gives the impression of the the architectural design which gained not only a visual attracelement of nature. In 1991 Ando stated: "I want to ground of a natural tree stand (Fig.1). Seen from 
szym społeczeństwie, równocześnie stworzyć miejsca, które przemowia do ludzkich zmysiów jak żjąca ciatem istota. Ponadto staram się odzyskać z historii, nie tylko formy czy style ale zasadniczy widok natury oraz życia, które wypełniaja ich otchłań - innymi słowy - wydobyć ducha kultury"

Z kolei w Water Temple Hompuku-ji architekt zmierzył sie $z$ kwestia przedstawienia symboliki raju obecna w Buddyźmie. Masao Furuyama pisze, że: Architekt wyobrazit sobie postać przemierzajaca staw zeten lotosów i sale pojawipostac pzed ra umiécit liptyczny staw o osiach 40 i 30 metrów. Nastepnie przecia a ken w polowi i umiés cil w korytarzu schody prowadzące pod powierzchnię wody. Schodzimy nimi jakbyśmy tonęli i znikali na dnie stawu. Tymczasem po zejściu wchodzimy do wypełnionej cynobrem pozaziemskiej przestrzeni"9. Ando chciał stworzyć salę, którą ludzie zapamiętaja. Tradycyjnie sale świątynne miały duże dachy. Jego pomysł opierał sie na zerwaniu z takim postrzeganiem wnetrza światyni przez odwiedzających ja wiernych. Ten efekt wyjatkowości uzyskał sprowadzając ich schodami "w głąb" stawu wypełnionego kwitnącymi lotosami - mającymi symboliczne powiązania z Buddyzmem ${ }^{10}$ W tej reajizacii podstawa idei projektowe stał sie geometrycznie ukszajtowany w formie elipsy staw beedacy jednocześnie zad aszeniem światyni, a prowadzace do niej zejściocześnie zadaszeniem świattyni, a prowadzące do hiej zejście symbolizuje droge - łącznik między codziennościa zycia a przestrzenią sacrum swiątyni. Woda staje się tu czyestetyczny w tworzeniu idei kompozycyjnej dla wspótczesnej formy architektoniczne

Woda jako element idei budynku jest wykorzystywana także w Komyo-ji Temple wzniesionej w małej miejscowości Saijo na wyspie Shikoku, gdzie biją liczne źródła. Tym razem - jak pisze Furuyama: „Ando zaproponował drewniana sale unosząca się na wodzie i otoczona delikatnym świattem. Drewniana sala główna pływa po stawie i jest przestrzenią stworzona $z$ wody - podstawowego elementu lokalnego krajobrazu"11. Tu dodatkowego znaczenia zyskuja refleksy i odbia w tafl Tudy podkré́lajce atrakcyjnść formy wywodzacia w taf wody pockér efekt „pływającej” świątyni czyni z niej miejsce mistycznego odosobnienia - sacrum oddzielonego od profanum.

Innym rodzajem miejsca modlitwy i kontemplacji zaproponowanym przez Ando jest budowla Meditation Space przy siedzibie UNESCO w Paryżu. Miejsce to jest uznawane za "przykład poszukiwania uniwersalnego sacrum", o którym Anna Wierzbicka pisze: „Obiekt ma charakter ponadreligijny - ma symbolizować pokój i być przestrzenią medytacji oraz indywidualnej modlitwy"12. Cylindryczna forma niewielkiej, betonowej świątyni, do której prowadzi charakterystyczna pochylnia, została ustawiona na wybrukowanej granitowym płytami niecce wodnego ogrodu. Do jej budowy użyto kamieni przywiezionych z Japonili, ktore to przetrwały wybuch bomby atomowej $W$ Hiroszimie. W zamyśle architekta po tak ukształtowanej posadzce została wprowadzona, pokrywająca ja cienka warstwa cieknącej, powierzchniowej wody, która delikatnie opływając kamienne nierówności i cylindryczna formę niewielkiej świątyni miała symbolizować oczyszcze- give nature's power a presence in contemporary society and provide thereby the kind of stimulating places that speak directly to man's every sense as a living, corporeal being. Moreover, retrieving form view of nature and life that runs through its depth - the spirit of culture, in other words"

In The Water Temple Hompuku-ji, in turn, the architect addressed the issue of presenting the symbolism of paradise present in Buddhism. Masao Furuywandering across a pond full of lotuses and a room appearing in front of them. (...) First Ando placed an elliptical pond with 40 and 30 metre axes on the top of the hill. Then he cut the reservoir in half and placed the stairs in the corridor leading under the drowning and disappearing at the bottom of the pond. Meanwhile, after descending, we enter the extra-terrestrial space filled with vermilion ${ }^{\prime \prime}$. Ando wanted to create a room that people will remember. Traditionally, the temple chambers had large ception of the interior of the temple by the faithcetion of the interior of the temple by the faith-
fuling it. The architect achieved this effect of uniqueness by leading them down the stairs "into the depths" of the pond filled with blooming lotuses - that have symbolic connotations with Bud-
dhism $^{10}$. The pond, and at the same time the roo of the temple shaped at the same time the roo of the temple, shaped geometrically as an ellipse,
became the basis of the work's design idea, while the descent leading to it symbolizes a path - a link between everyday life and the sacred space of the temple. Water here becomes a visible element of symbolism used as an aesthetic means in creating a composition
tectural form

Water as an element of the idea of the building is also used in Komyo-ji Temple erected in the smal town of Saijo on the island of Shikoku famous for numerous gushing hot springs. This time - as Fufloating on the water and surrounded by a relicat light. The wooden main room drifts on the pond and is a space created from water - the basic element of the local landscape" ${ }^{\prime 11}$. Here, reflection and mirroring in the water surface gain additiona significance, underlining the attractiveness of the
form which originates from the tradition of en construction of the ancient Japan. The resulting "floating" temple effect turns the temple into mystcal seclusion - where the sacred is separated from the profane.

Another type of a place of prayer and contempla-
tion proposed by Ando is the Meditation Splactis tion proposed by Ando is the Meditation Space place is considered an "example of the quest for the universal sacrum", which Anna Wierzbicka describes in the following way: "The structure has an non-denominational character - it is to symbolize ual prayer ${ }^{\prime \prime 2}$. The cylindrical form of a small concrete temple with a characteristic ramp leading to the interior was situated atop the pond of a water garden paved with granite slabs. The stones tha had survived the atomic bomb explosion in Hiroshima were brought from Japan to construct it,
According to the architect's design, a thin layer of trickling surficial water was placed over the thus shaped bottom floor, covering it. Gently flowing nie dusz osób, które zginęły podczas wojny. To wyjątkowo ry w realizacji całego założenia składającego się na "Ogrodu Medytacji" pokazuje kunszt Ando w dążeniu do tworzenia ide projektu opartej na symbolice jaką niesie za sobą element wody w architekturze.

3. Sposoby wykorzystania elementu wody w niesakralnych realizacjach Tadao Ando

Tadao Ando z równym powodzeniem stosuje element wody w budynkach niesakralnych. Jak sam podkreśla: Wykody nia wymar dún z japonska my - sotycy zatem tylko architektury o przeznaczeniu religijnym - ad przeznczena projektowa jego dokonaniom nieza zinie od przeznczenia projektowanego budynku, czyniąc z niego uniwersalny, transcendentny czynnik tozsamosci kulturowej, własciwy dla dorobku realizacyjnego Ando. Warto podkreślic ze Ando jest twór samoukiem, utożsamianym z architekturą betonową, ktora czerpie swe zrodła zarowno $z$ tradycj ascetycznej japonskiej estetyki, jaki i z tendencji minimalistycznych bliskich dewizie Miesa van der Rohe "less is more". Rzadziej z kolei bywa kojarzony z architekturą wykorzystująca element wody do nadawania duchowego wymiaru idei architektonicznej w projektach. Jednak, gdy blizej przeanalizujemy jego dorobek realizacyjny okaze się, ze element wody wykorzystywany jest na tyle często w jego projektach, ze trudno znaleźć we współczesnej architekturze mogącego mu dorównać twórcę, który z równym powodzeniem potrafi w tak subtelny sposób stosować ten element natury do kształtowania wyjątkowej idei i kompozycyji budowli.

Ando z upodobaniem wykorzystuje element wody w projektach muzeów. Najczęściej stosuje całe płaszczyzny wodne do aranżowania i przetwarzania otoczenia przylegającego bezpo średnio do budynków. Tak jest w przypadku choćby Children's Museum w Himeii (Hyogo, w przypadku chocby Children's seum (Kawakami, Okoyama, Japonia, 1991-1994), Museum

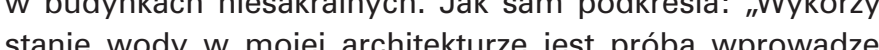
wia wyiar wuchowe któy jest bezpoś dnio zwiazze

over the stone inequalities and the cylindrical form of the small temple, the water was to symbolize died during the war. This extremely sophisti had and subtle use of this natural element in the imple mentation of the entire complex of the "Garden of Meditation" shows Ando's artistry in the pursuit of creating the design idea based on the symbolism

3. Ways of using water in Tadao Ando's non-sa-

cral works

Tadao Ando uses water in non-sacral buildings with equal success. As he emphasizes: "The use to bear a spiritual dimension which is directly related to Japanese thought and tradition"13. This "spiritual dimension" does not concern only the architecture of religious destination - the sacred (nents regardless of the purpose of the demplishbuilding, making it a universal, transcendent factor of cultural identity, typical of Ando's creative achievements. It is worth emphasizing here that Ando is a self-taught artist, identified with concrete architecture that draws its roots both from the as minimalist trends close to Mies van der Rohe's "less is more" motto. He is slightly less often associated with the architecture that uses water to give a spiritual dimension to the architectural idea in projects. However, when one analyses the archiout that the element of water is so frequ, it turns plied in his projects that it is difficult to find anothmatch him in the successful use of this element of nature in such a subtle way to shape the unique wea and composition of ha bullding.

Ando has a fondness for using the element of uses whole water planes to arrange and process the surroundings adjacent to buildings. This is the case of the Children's Museum in Himeji (Hyogo, Japan, 1987-1989), Nariwa Museum (Kawakam, ture II (Hyogo, Jan, 1993-1996) or Modern At

1. Modern Art Museum of Fort Worth (Fort Worth, Texas, USA, 1997-2002) - przykład płytkiego i rozleglego zbiornika wodnego, przylegaja

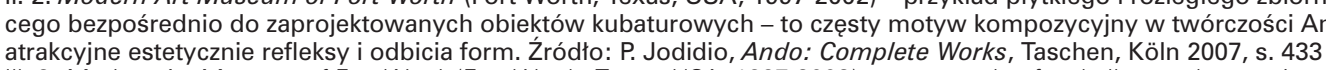

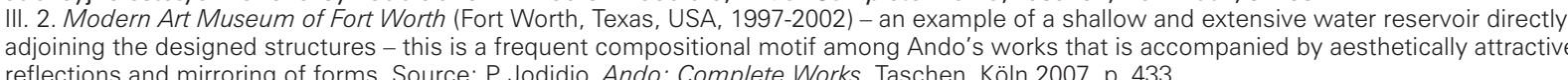

1. 3. Naoshima Contemporary Art Museum, Annex (Naoshima, Kagawa, Japonia, 1993-1995) - eliptyczna forma atrium z centralnie zlokalizo-

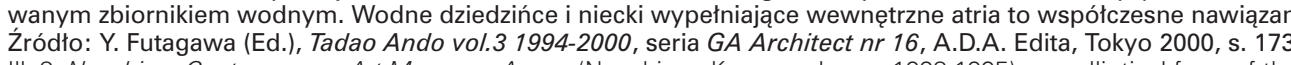

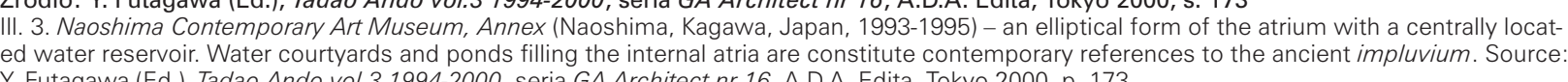
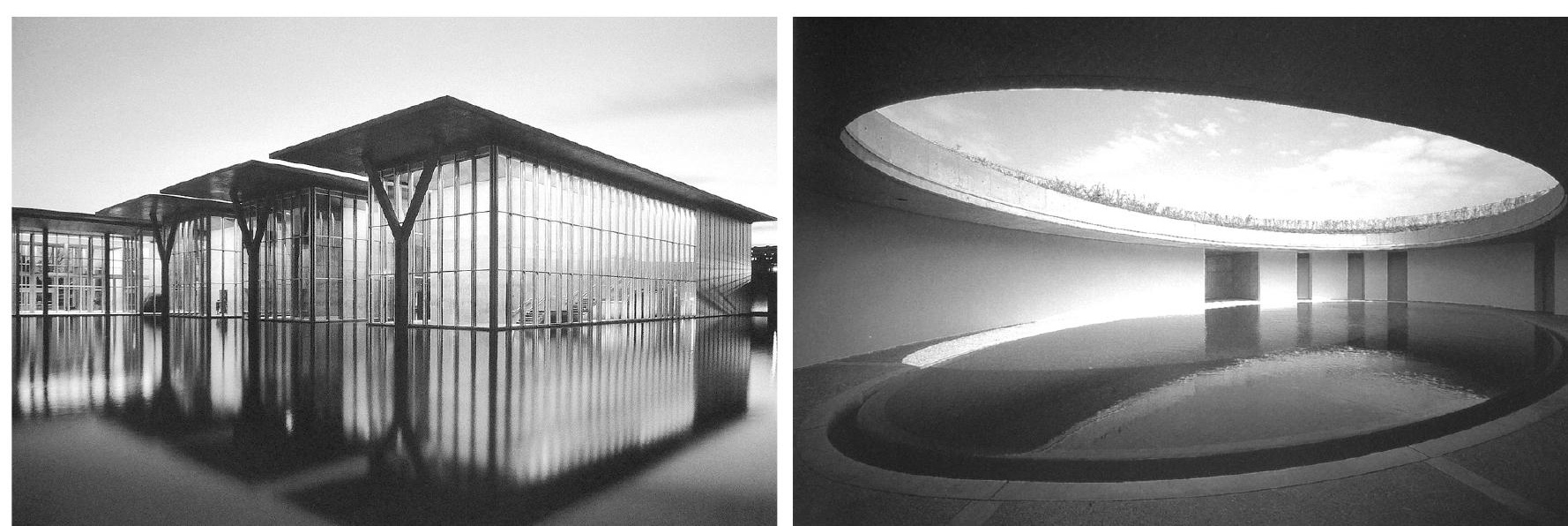


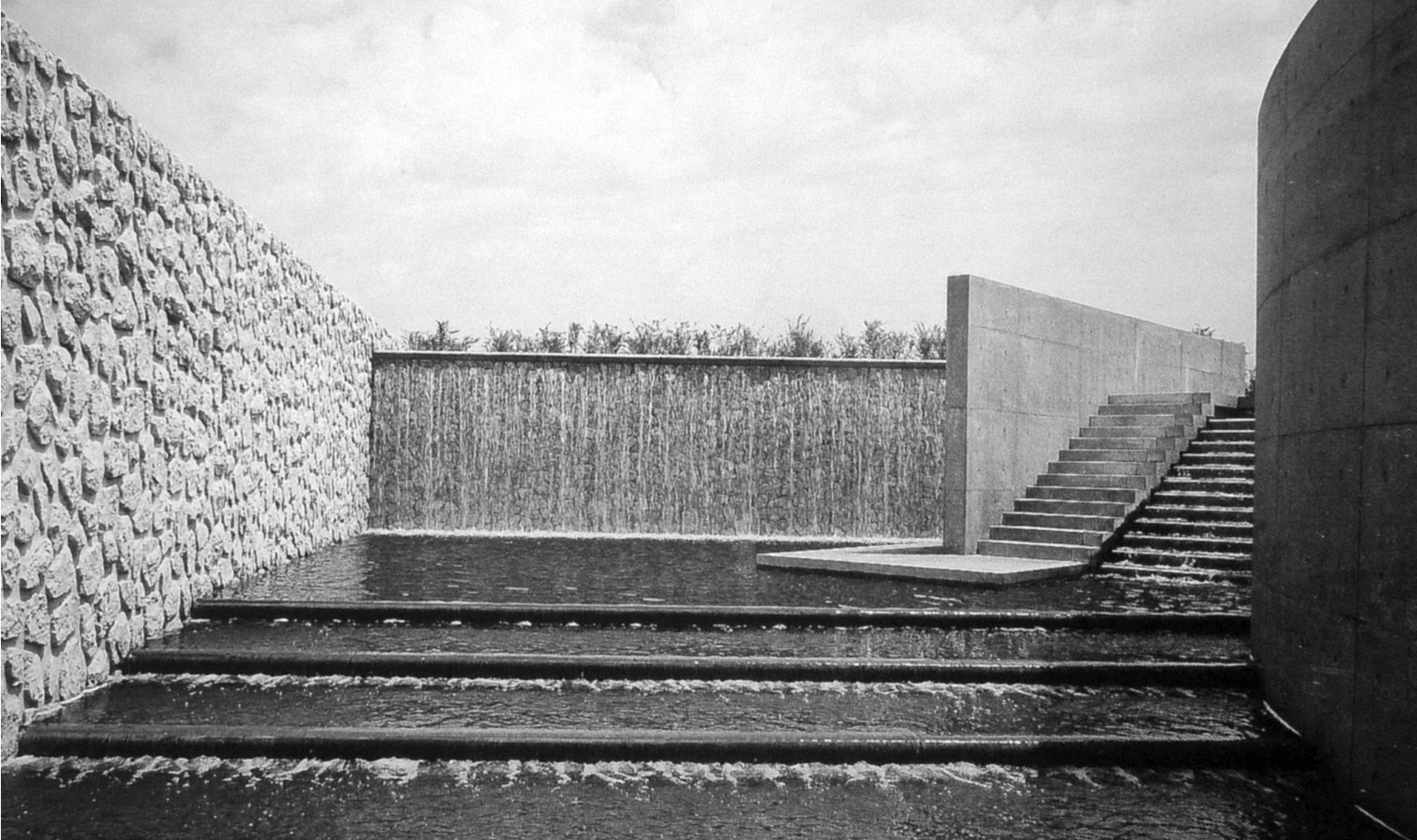

LITERATURA

ThC Fuyama M., Fadao Ando. Goomona Wdakkej przestzent, Taschen/ [2] Futugawa Y. (Ed).). Tadao Ando Details 2, A.D.A. Edita, Tokyo 2003.
[3] Futagawa Y. (Ed.), Tadao Ando vol.3 1994.2000 , seria GA Architect $n$ r

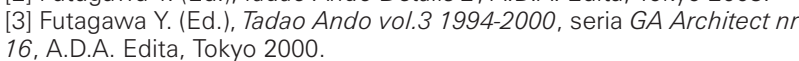

3/2004. Jencks Ch., Kropf K., Teorie i manifesty architektury wspótczesnej, [6] Jodidio P., Ando: Completete Works, Taschen, Köln 2007.

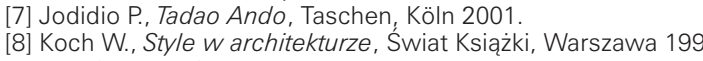

9) Law S., Filozofia, Hachette Polska, Warszawa 2009

[10] Monestiroli A., Tryglit ‘ metopa: dziewięć wykkadów o architekturze,

ukowe Politechniki Warszawskiei, Seria Architektura, zeszyt 11, Oficyna

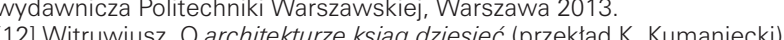
Prószyńki i S-ka, Warszawa 2004.
BIBLIOGRAPHY

11] Furuyama M., Tädao Ando: Geometria ludzkiej przestrzeni. [2] Futugawa Y. (Ed.), Tadao Ando Details 2, A.D.A. Edita, Tokvo 2003 (1) Futagawa Y. (Ed.), Tadao Ando D

W. [5] Jencks Ch., Kropf K., Teorie i manifesty architektury wspótczesn [6] Jodidio P., Ando: Completete Works, Taschen, Köln 2007.

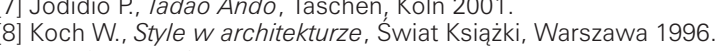
9] Law S., Filozofia, Hachette Polska, Warszawa 2009 [10] Monestiroli A., Tryglif i metopa: dziewiẹć wyktadów o architek naukowe Politechniki Warszawskiej, Seria Architektura, Issue 11, Ofi. Prószyńki i S-ka, Warszawa 2004

il. 6. Naoshima Contemporary Art Museum, Annex (Naoshima, Kagawa, Japonia, 1993-1995) - widok na wnetrze Ogródu kaskadowego, to
przyktad wykorzystania przzez Ando różnych form płynacej wody w jednym miejscu, tij. schodkowo uksztattowanych kaskad, ścian - po których dynamicznie spływa woda, tworzac rodzaj wodospadu oraz progów wodnych oddzielających uskokowo płaszczyzny wodnej niecki. Żródto: III. 6. Naoshima Contemporarn Art Museum, Annex (Naoshima, Kagawa, Japan, 1993-1995) - view of the interior of the Cascading Garden is an

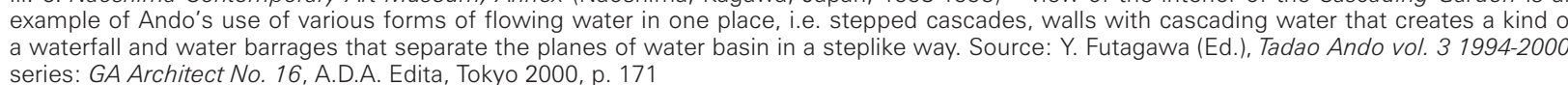

zycji do stałości betonowej materii ujarzmionej w zastygłych ksztaltach, tworzac poczucie napiecciawywalajacego emocje u wrażliwego widza (odbiorcy). Z trwałością materii kontrastuje ulotność światła i płynność wody. Jest to główny element budujący atrakcyjność tej architektury. Antonio Monestiroliego twierdzi, że: "Ostatecznym celem architektury jest wzruszać"14. Woda wykorzystywana jako element idei i kompozycii w twórczości Ando służy do oddziaływania na zmysły ludzką wyobraźnie partycypujac w tym oddawaniu ostatecznego celu architektury jakim jest zdolnosc do wzruszania.

\section{NDNOTES}

Solska, Warszawa 2009 s. 232 .

. Witruwiusz, O architekturze ksiagg dziesięć, przekład K. Kumaniecki, Prószýnk ${ }^{3}$ W. Koch, Style w architekturze, Świat Ksiaziki, Warszawa 1996, s. 346, 444. -Cyt. za: Ch. Jencks, K. Kropf, Teorie i manifesty architektury wspolczesnej, Gru 5M. Iwata, Architektura Tadao Ando, w: Architektura \& Biznes, Nr 3/2004, s. 66-

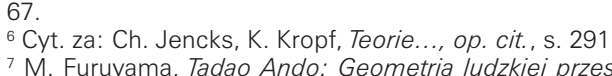

, Paschen/TMC Art, P. Jodidio, Tadao Ando, Taschen, Köln 2001, s. 78

Y. Futugawa (Ed.). Tadao Ando Details 2. A. D. A. Edita. Tokyo 2003, s. 78 M. Furuyama M.., Tadao...., op. cit.,., s. 55 .

echniki Warszawskiej, Seria Architektura, zeszzyt 11. Oficyna wydaunnicza Politechniki Warszawskiej, Warszawa 2013, s. 58.

.

ka Krakowska, Kraków 2009, s. 24 the attractiveness of this architecture. Antonio Monesticlive says: "The ultimate goal of architecelement of the idea and composition in Ando's creative work serves to influence senses and hi man imagination, thus participating in reaching the ultimate goal of architecture, which is the

\section{ENDNOTES}

S. Law, Filozofia, Hachette Polska, Warszawa 2009, p. 232 1996, pp. 346,444 .
4 Quoted after: Ch. chitektury wspótczesnej, Grupa Sztuka Architektury, Warsza-

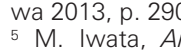

A Antitektura Tadao Ando, in: Architektura 6 Quoted after: Ch. Jenckss., K. Kropf, Teorie...., op. cit., p. 291 Taschen/TMC Art, Köln 2008, p. 34 Ko

8. Podidio, Tadao Ando, Taschen, Köln 2001, p. 78

10 Y. Futugawa (Ed.), Tadao Ando Details 2, A.D.A. Edita, To kyo 2003, p. 78.
$11 \mathrm{M}$. Furuyama M.

12 A. M. W. Wierzbicka, Architektura jiako narra
1 Prace naukowe Politechniki Warszawskiej, Seria Architektu 13. P. Jodidio, Ando: Complete Works, Taschen, Köln 2007. p. 15 . Monestiroli, Tryglifi metopa: dziewiéć wyktadón o ar
14 A
chitekturze, Politechnika Krakowska, Kraków 2009, p. 24. 